\title{
Modified Method for Chemical Extraction of Palynomorphs from Petroleum Source Rocks
}

\author{
Abbas H. Al-Shukry and Wedad H. Al-Dahhan \\ Department of Chemistry, College of Science, Al-Nahrain University.
}

\begin{abstract}
Palynomorphs were efficiently separated from paleogene rock samples using $\mathrm{HCl} / \mathrm{HF}$ mineral acids to digest carbonaceous silicates of inorganic sedimentary rocks matrix to extract the palynomorphs individually using cellosize solution, then fixed upon microscope glass slides for visual optical test . The traditional procedure was developed by the control of acid concentrations, residence time as well as the use of ultra sonic bath to obtain well structured structures useful for visual optical tests. The data of analytical chemical analysis (TOC\%, S2, HI and vitrinite scale) for source rocks confirm the accuracy of the modified procedure to predict H.C. product of the well whether its oil or oil/gas prone .
\end{abstract}

Keywords: Chemical Extraction, Palynomorphs, Source rocks, Visual optical tests.

\section{Introduction}

The increasing importance of petroleum prospecting activities to predict hydrocarbon prolific sites without the risk of costly well drilling misconceptions based on non precious estimations, petroleum geological surveys should be triggered by the encouraging data of the visual optical examinations for paleogene fossils and their related biomarkers (linear $\mathrm{C}_{23}-\mathrm{C}_{35}$ n-paraffins as well as cyclic hydrocarbons e.g. pristine and phytane)

Palynomorphs are well preserved as structured organic matters (SOM) of sizes < 200 micrometer (Table (1)) [1]. All over the World most polynomorphs had been preserved by anoxic (reducing) depositional environment and were undergone digenesis and catagenesis metamorphisms, their carbon frame work maintain a stabilized complex print characteristics which applied in the field of petroleum geochemistry [2] to minimize risk assessment of costy drilling operations in order to find economic hydrocarbon prone reservoirs due to misconception in data management; therefore correlation of palynomorphs types as well as chemical analytical data e.g. total carbon organic matter (TOC\%), hydrogen index, vitrinite scale, thermal alteration index (TAI) and the concentration of hydrocarbon in rock according to their paleogene stratography and environmental deposition conditions provide better understandings about the origin of crude oil or natural gas resources as well as their path of migration processes from source rock to reservoirs (Table (2)) [3].

The usual procedure to prepare slides for microscope visual optical test begins by paleogene rock dissolution with mineral acids e.g. hydrochloric and hydrofluoric (for all ages) to dissolve the inorganic matrix of carbonates and silicates in order to extract palynomorphs by cellosize solution as well structured individual entities to be ready for optical visual test by electron microscope :

$\mathrm{CaCO}_{3}+2 \mathrm{HCl} \longrightarrow \mathrm{CaCl}_{2}+\mathrm{H}_{2} \mathrm{O}+\mathrm{CO}_{2}$

Calcium carbonates (in limestone)

$\mathrm{MgCO}_{3}+2 \mathrm{HCl} \longrightarrow \mathrm{MgCl}_{2}+\mathrm{H}_{2} \mathrm{O}_{+} \mathrm{CO}_{2}$

Magnesium carbonate (dolomite)

$\mathrm{SiO}_{2}+6 \mathrm{HF} \longrightarrow \mathrm{H}_{2} \mathrm{SiF}_{6}+2 \mathrm{H}_{2} \mathrm{O}$

Silicates (in limestone) 
Table (1)

Structured and Unstructured Organic Matter Palynomorphs [1].

\begin{tabular}{|c|c|c|c|c|}
\hline $\begin{array}{c}\text { Structured } \\
\text { Organic Matter } \\
\text { (STOM) }\end{array}$ & Zooclasts & \multicolumn{2}{|c|}{$\begin{array}{c}\text { Unstructured Organic } \\
\text { Matter } \\
\text { (USTOM) } \\
\end{array}$} & $\begin{array}{c}\text { Structured } \\
\text { Palynomorphs }\end{array}$ \\
\hline \multirow{2}{*}{$\begin{array}{l}\text {-Phytoclasts } \\
\text {-Wood } \\
\text {-Bark } \\
\text {-Charcoal } \\
\text {-Black particles } \\
\text {-Cuticle tissues } \\
\text {-Non cuticle tissues } \\
\text {-Fungal } \\
\text {-Tubes }\end{array}$} & $\begin{array}{l}\text {-Graptolie sicule } \\
\text {-Arthropod cuticle }\end{array}$ & $\begin{array}{l}\text { Organic } \\
\text { Matter } \\
(\mathrm{OM})\end{array}$ & $\begin{array}{l}\text { Amorphous } \\
\text { Organic } \\
\text { Matter } \\
\text { (AOM) }\end{array}$ & \multirow{2}{*}{$\begin{array}{l}\text {-Acritarches } \\
\text {-Chitinozoans } \\
\text {-Chloro cocatean } \\
\text {-Algae } \\
\text {-Dinoflagellate cysts } \\
\text {-Foraminiferal } \\
\text { linings . } \\
\text {-Fungal selerotia } \\
\text {-Spores and pollen } \\
\text { grains } \\
\text {-Scolecondonts } \\
\text {-Zygnematalean and } \\
\text { green algae }\end{array}$} \\
\hline & & $\begin{array}{l}\text {-Solid resins } \\
\text {-Bitumen }\end{array}$ & $\begin{array}{l}\text {-Terrestrial } \\
\text {-Aquatic }\end{array}$ & \\
\hline
\end{tabular}

The aim of this research is to extract complete palynomorphs entities by modified chemical methods based on solvent extraction techniques used for accurate optical visual test surveys for hydrocarbon prone sites.

\section{Requirements:}

Chemicals:

Hydrochloric acid (concentrate) pure (BDH), Hydro fluoric acid (concentrate) pure (Carlo Erba), Nitric acid (concentrate) pure (BDH), Poly vinyl alcohol (PVA ) (Ridel-De Hain), Canada balsam (BDH), Distilled water and Absolute ethanol (BDH).

\section{Instrumental:}

Plastic beakers, stirrers, glass ware, Magnetic stirrer hot plate (Gallen Kamp), Ultra sonic bath $50 \mathrm{khz} / \mathrm{sec}$ (Neyo), Optical microscope (400 X), Ventilated fume hood, Electronic $\mathrm{pH}$ meter, 2 digits (Hana), Standard $\mathrm{pH}$ test paper $(\mathrm{BDH})$ and Centrifuge (Gallen Kamp) .

\section{Experimental Procedure:}

1-(12) samples (cores and cuttings) from Makhul-2, Qara chug-2, Taq taq-1, Butma15, Ajeel-8 oil extractor wells encountered from Jurassic era for Butmah, Sargelu and Naoekelekan formations . were crushed for 24 hours with the aid of a ball mill.

2-The samples were sieved with a molecular sieve apparatus for grades of $5 \mathrm{~A}$ to $50 \mathrm{~A}$ $(\leq 200 \mu \mathrm{m})$ particle size, fractions of $50 \mathrm{~A}$ taken, washed in dilute alkali to peptize the clay minerals in rock samples, then with distilled water upon a plastic filter of $20 \mu \mathrm{m}$ mesh size to wash out dirt and debris colloids .

3- $(5-10 \%) \mathrm{HCl}$ was added to each sample in (2) to digest Calcium and Magnesium carbonates of the sedimentary rock matrix; the samples left overnight to ensure complete reaction.

4-Samples were washed many times with distilled water to remove the traces of acid $(\mathrm{pH}$ was measured using a standard $\mathrm{pH}$ paper or a 2-digit electronic $\mathrm{pH}$ meter).

5-Concentrate hydrofluoric acid was added (in a ventilated fume hood) to samples to destroy Calcium silicates, the reaction mixtures were left over night.

6-Samples were washed many times with distilled water to the normal $\mathrm{pH}(\sim 7)$.

7-Samples were boiled with concentrate $\mathrm{HCl}$ for 2 minutes, cooled and washed with distilled water to normal $\mathrm{pH}$.

8-The treated rock samples transferred to 20 micrometer nylon mesh filtering screen and washed by distilled water to remove dirt and clays, left over night.

9-The residue for each sample in step (8) transferred to a test tube with the aid of a glass dropper to be treated with ultra sonic bath $(50 \mathrm{khz} / \mathrm{sec})$ for 30 seconds to deflocculate organic debris from 
polymorphs, then centrifuged with high speed centrifuge to separate water, the water was spoiled out by turning the tube upside down.

10-The solid residues in step (9) were mixed with cellosize solution (4\% polyvinyl alcohol in ethanol) to extract polymorphs as individual entities.

11-Droplets of cellosize containing extracted polymorphs from step (10) were distributed upon labeled microscope glass slides and left to dry gently with aid of electric oven at $105 \mathrm{C}^{\mathrm{o}}$ to dryness.

12-The glass slides samples from step (11) were stick with cover slides by Canada balsam, dried, cleaned by clean cloth and preserved into clean dry boxes ready for microscope optical visual examination.

Table (2)

Palynomorphs and Chemical Analysis Data for Some Geological Formations.

\begin{tabular}{|c|c|c|c|c|c|c|c|c|c|}
\hline & Formation & Locations & Period & TOC\% & $S_{2}$ & $H I \%$ & TAI & Palynomorphs & Status \\
\hline 1 & Sulaiy & $\begin{array}{l}\text { Southern } \\
\text { Iraq and } \\
\text { Kuwait }\end{array}$ & Jurassic & $0.1-1$ & & $\begin{array}{c}200 \\
-300\end{array}$ & & $\begin{array}{l}\text { Dinoflagellates, } \\
\text { Spores, Pollen grains } \\
\text { Foraminiferal linings }\end{array}$ & $\begin{array}{c}\text { Oil } \\
\text { Prone[3] }\end{array}$ \\
\hline 2 & $\overline{~ T a n n u m a ~}$ & $\begin{array}{c}\text { East } \\
\text { Baghdad }\end{array}$ & Jurassic & 0.5 & $\begin{array}{c}2.3- \\
18.5 \\
4.5-23^{*}\end{array}$ & $\begin{array}{l}150 \\
450-\end{array}$ & $\begin{array}{c}2.8- \\
3.0\end{array}$ & $\begin{array}{l}\text { Dinoflagellates, } \\
\text { Spores, Tasmanite }\end{array}$ & $\begin{array}{c}\text { Oil } \\
\text { Prone[4] }\end{array}$ \\
\hline 3 & Khasib & $\begin{array}{c}\text { East } \\
\text { Baghdad }\end{array}$ & Jurassic & $\begin{array}{l}\text { Very } \\
\text { low }\end{array}$ & & & 2 & & $\begin{array}{c}\text { Oil } \\
\text { Reservoirs } \\
{[4]} \\
\end{array}$ \\
\hline 4 & Sargelu & $\begin{array}{l}\text { Northern } \\
\text { Iraq }\end{array}$ & Jurassic & 4 & & & & $\begin{array}{l}\text { Dinoflagellates, } \\
\text { Spores, Pollen grains, } \\
\text { Foraminiferal linings }\end{array}$ & $\begin{array}{c}\text { Oil } \\
\text { Prone[5] }\end{array}$ \\
\hline 5 & $\begin{array}{l}\text { Butmah and } \\
\text { Naeokelekan }\end{array}$ & $\begin{array}{l}\text { Northern } \\
\text { Iraq }\end{array}$ & Jurassic & $\begin{array}{l}11.81 \\
3.00\end{array}$ & $\begin{array}{l}45.53 \\
6.33\end{array}$ & $\begin{array}{l}386 \\
211\end{array}$ & $\begin{array}{l}2.8 \\
3.0\end{array}$ & $\begin{array}{l}\text { Dinoflagellates, } \\
\text { Spores, Pollen grains, }\end{array}$ & $\begin{array}{c}\text { Oil Prone } \\
\text { Oil/Gas } \\
\text { Prone }\end{array}$ \\
\hline 6 & Abu-Gabra & Sudan & Cretaceous & 1.43 & $\begin{array}{c}338- \\
546\end{array}$ & 83 & & & $\begin{array}{c}\text { Unmature } \\
\text { Kerogene } \\
{[6]} \\
\end{array}$ \\
\hline 7 & Simsima & UAE & Cretaceous & $\begin{array}{c}0.4- \\
1.3\end{array}$ & & & & $\begin{array}{l}\text { Dinoflagellatecysts, } \\
\text { Spores, Pollen, Plant } \\
\text {-cuticle, fungal spores }\end{array}$ & $\begin{array}{c}\text { Probable } \\
\text { H.C. } \\
\text { prone ..[7] }\end{array}$ \\
\hline 8 & $\begin{array}{c}\text { Colorado } \\
\text { group } \\
\text { Albian- } \\
\text { Santavi }\end{array}$ & $\begin{array}{c}\text { USA } \\
\text { Canada }\end{array}$ & Cretaceous & $1-3$ & $\begin{array}{l}170- \\
500\end{array}$ & 106 & & $\begin{array}{l}\text {-Marine } \\
\text { dinoflagellates } 20 \% \\
\text { unsaturated and } 1-7 \% \\
\text { Degraded phytoclasts. } \\
\text { Amorphous organic } \\
\text { matter (AOM) } 70 \% \\
\end{array}$ & $\begin{array}{c}\text { Gas prone } \\
{[8]}\end{array}$ \\
\hline
\end{tabular}

* Other part of the formation. 


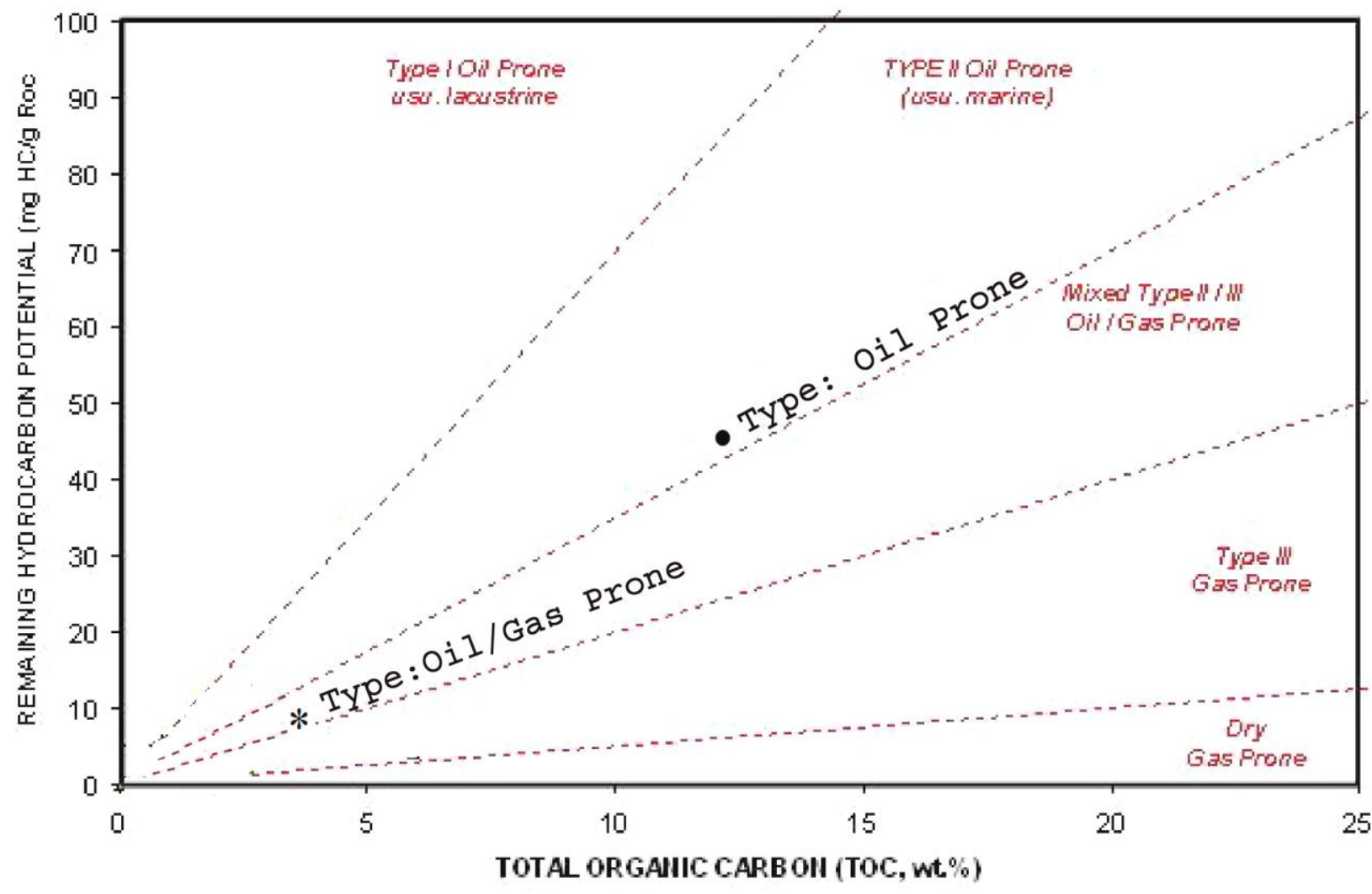

Fig.(1) Effect of Hydrocarbon Potential, $S_{2}$ with TOC\% on Hydrocarbon Type Production [ 9 ]. Oil prone sites of Sargelu and Tannuma Formations according to this research.

* Oil/Gas prone sites of Sargelu and Tannuma formations according to this research.

\section{Results and Discussion}

Palynomorphs extraction researches have been growing exponentially all over the World, they are considered the trusted magic key for prolific hydrocarbon sites predictions. Iraqi formations consist mainly of dolomitic limestones sedimentary rocks which can be dissolved completely with $\mathrm{HCl} / \mathrm{HF}$ mineral acids leaving palynomorphs as free well structured entities.

Types and shapes of the separated fossils from rock samples when correlated to their analytical chemical data and according to paleogene stratigraphy of their home formations (Table (2)) asset petroleum geologist to predict the the type of the prolific hydrocarbon well sites, thus minimizing the costy drilling misleading. The visual optical test for palynomorphs of Sulaiy, Tannuma, and Sargelu formations showing dinoflagellate cysts, pollen spores, foraminiferal linings and algae correlated to comparable chemical data analysis of TOC\%, $\mathrm{S}_{2}$ ( $\mathrm{mg} \mathrm{H.C} / 1$ gm rock), HI (Hydrogen Index), Tmax and TAI (Temp. alteration index) confirm oil prolific sites, meanwhile the chemical analytical data for Kassib formations indicate no hydrocarbon assessments but only they are oil reservoirs due to impermeable rock formations. Fig.(1) $[9,10]$ showing standard curves for TOC\% versus $S_{2}$ values of rock samples related to well known formations, the confined area between curves restrict the sites under study whether oil, oil-gas mixture or gas producers, accordingly the samples of the Iraqi pre mentioned formations are crude oil prone only if their TOC\% versus $S_{2}$ values are located upon the curve.

Abu Gabra (Sudan) and Simsima (UAE) are newly formed constructions (Cretaceous era) thus they will be prolific in far future due to their immature kerogene. Colorado group formations showing different values of chemical analysis for kerogene especially degraded plant cuticles (up $7 \%$ ) with amorphous organic matters $(70 \%)$, therefore these sites are gas prone.

According to the analytical chemical data for this research which were carried at Oklahoma University and Geomark Research, 
Inc. Houston, Texas shown in (Table (2), row-5) confirm that Sargelu, Butmah and Naeokelekan formations the major parts of the Mesopotamian basin are petroleum and petroleum / gas mixed wells prone.

Total organic carbon percent (TOC $\%=11.81,3.0)$ was found by GC-rock eval pyrolysis, total organic constituent $\mathrm{S}_{2}$ (mg H.C/1 gm rock) was 45.53, 6.33 indicating high hydrocarbon potential sites and thermal alteration index (TAI $=2.8,3.0)$ respectively depicts light brown to brown petroleum resources. Visual optical examinations for microscope slides of the studied samples (Figs. (2-6)) showing dinoflagellates, spores and pollen grains, algae as as well as foraminiferal linings polymorphs of good kerogene maturity formed under anoxic depositional environments since Jurassic era, the slides were more pronounced, clear and well structured entities due to the modification in extraction procedure over the traditional one [1] especially in finely crushed samples by ball mill, sieving by fractionating molecular sieve apparatus and the more important step reducing the time of sonic bath for samples to 30 seconds in stead of 5 minutes to get rid of destroyed polymorphs slides.

All over the World chemical analysis of rock samples for the sites of the completely studied geological formations using most advanced apparatus techniques e.g. computerized GC-Mass oval pyro analyzer $[10,11]$, X-ray diffracto meters and analogdigital microscopes as constituents of most advanced chemical laboratory giving rise to most fruitful chemical data help for the prediction of economic hydrocarbon prone sites as well as their production states whether crude oil and/ or gas.

Moreover determination of ${ }^{13} \mathrm{C} \&{ }^{12} \mathrm{C}$ isotopic ratio is necessary to determine the geologic age of the formations, oil-oil correlation and oil- rock correlation factors [12]

Such valuable art of experience save millions of dollars when discovering new well sites generating huge quantities of hydrocarbons the novel source of energy now and then, knowing that this technique is one of enormous activities such as siezming, radiation, sonic and satellite scanning.

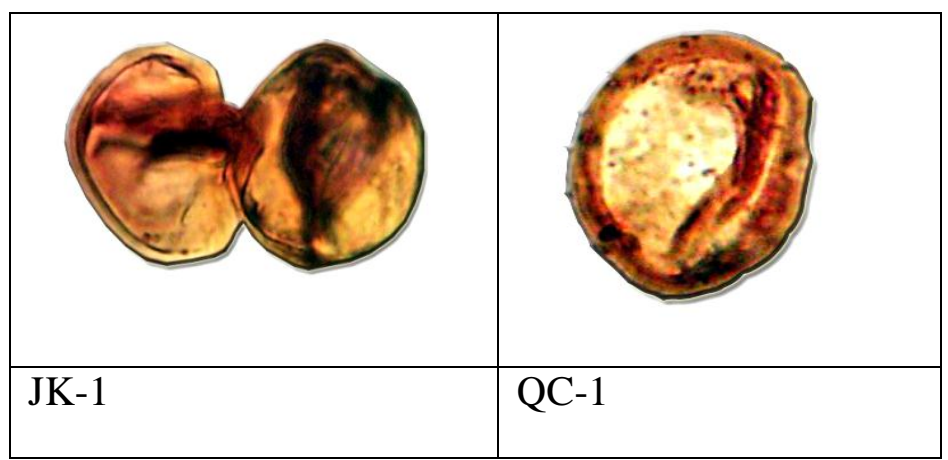

Fig.(2) Dinoflagellates.

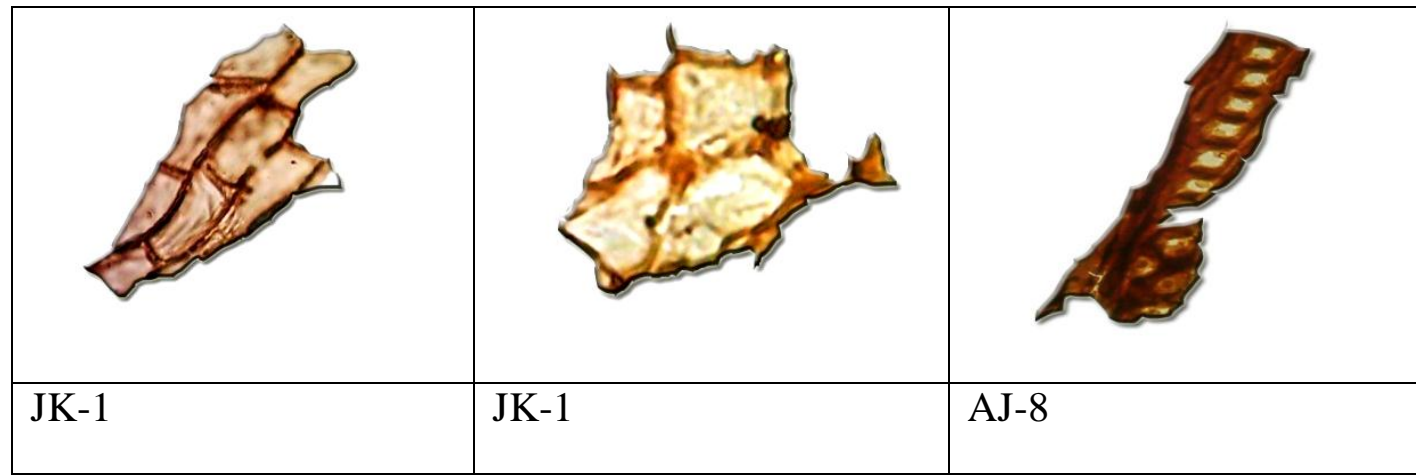

Fig.(3) Alga. 


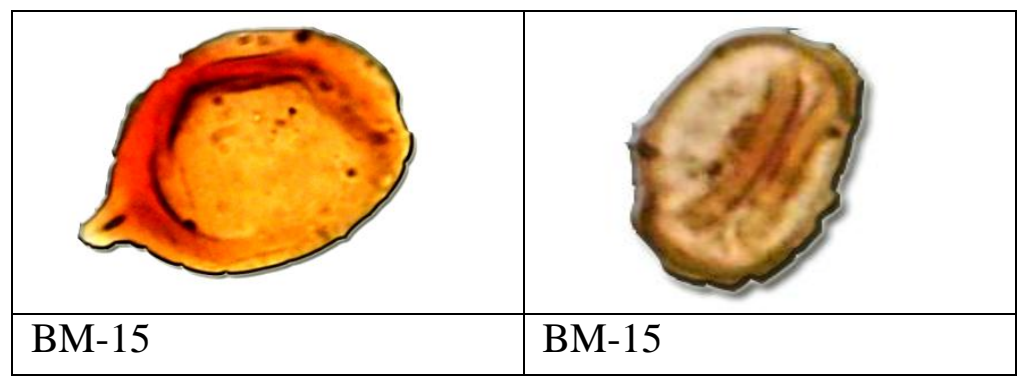

Fig.(4) Spores \& Pollen.

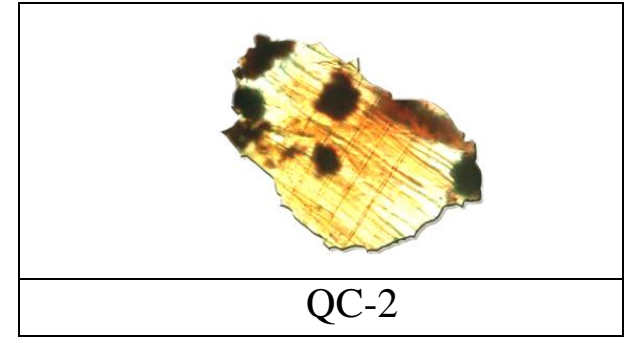

Fig.(5) Forminiferal linings.

\section{References}

[1] Jones T. P and Nick P. Rowe "Plants and Spores", Modern Tecnologies (Oct. 2000) pp 194-195.

[2] China J. Geo Chem. 28 (2009) pp 314319.

[3] Al-Ameri T. K, AL-Musawi F. S and Batten D. J, Cretaceous Research 20 (1999) pp 359-363.

[4] Thamer K. Al-Ameri and Riyad Y. AlObaydi, Arab Geosociety (2010).

[5] Al-Ahmed A. A., Al-Shukry A. H. and Al-Dahhan W. H., Proceeding of $3^{\text {rd }}$ Scientific Conference of the college of science, University of Baghdad 24 to 26 march 2009.

[6] Mustafa A. A and Tyson R. V, J.of Petroleum Geology V25 issue 3 (July 2002) pp 351-366.

[7] El-Gawad E. Ebd, Abdelghany O, Lotfy M. M, Abu Saima M and Hashem W, Australian Jornal of Basic and Applied Science, 4(8): 3526-3545, (2010).

[8] Buckly, L. and Tyson, R.V, Summary of Investigations, vol-1(2003).

[9] Tissot, B. P, Walte D. H. "Petroleum Formation and Occurrence" (1984) $2^{\text {nd }}$ edn, Sprines, Berlin, Heidelbers, New York pp-699.

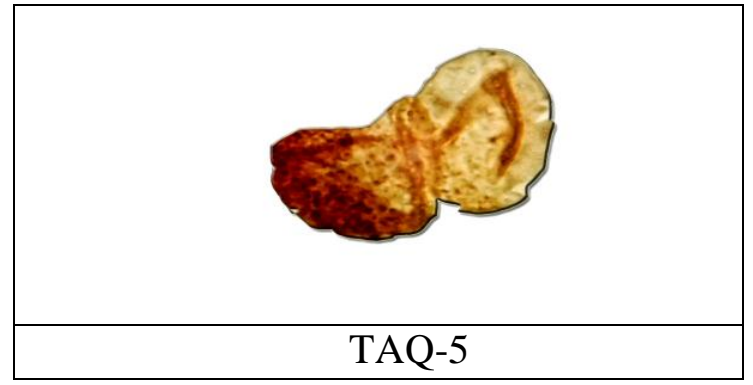

Fig.(6) Amorphous organic matter (AOM).

[10] Hunt, J. M "Petroleum Geochemistry and Geology" (1995) W. H Freeman and Company, New York, pp-743.

[11] Peters, K. E, Walters C. C, and Moldowan, J. M. "The Biomarker Guide / Biomarkers and Isotopes" (2005) Vol. 1 \& 2, Cambridge University Press. pp-250.

[12] Sofer, Z. "Stable Carbon Isotope Composition of Crude Oils", AAPG Bull (1984) pp 31-49.

الخلاصة - مات

تم فصل المتحجرات المجهرية ل للصخور المصدرية المولدة للهيدروكربونات بكفاءة وذلك باذابة المزيج اللاعضوي للصخورالرسوبية (الكاربونات والسيليكا) باستخدام الحوامض المعدنية (الهيدركلوريك والهيدروفلوريك) ومن ثم استخلاصها بواسطة "السيللوسايز" لتهيئتها للفحص البصري. تم تطوير طريقة العمل التقليدية المنبعة في هذا المجال من

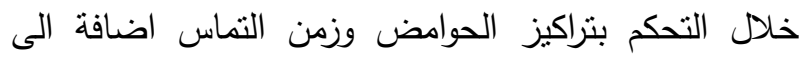
معاملة النماذج بالموجات فوق الصوتية للحصول على بلى كيانات منفردة واضحة المعالم. ان نتائج "الفحص البصري"

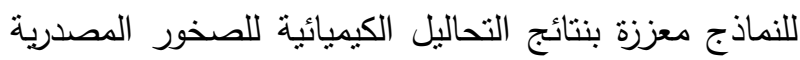
(نسبة الكاربون العضوي الكلية، نسبة الهيدروكاربون، المؤشر

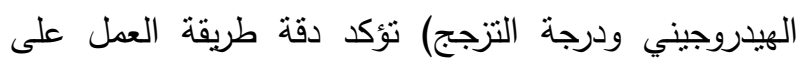
تحديد انتاج البئر للنفط او النفط والغاز معاً. 